\title{
ARTICLES
}

\section{Heterogeneous spectrum of mutations in the Fanconi anaemia group A gene}

\author{
M Wijker ${ }^{1}$, NV Morgan², S Herterich ${ }^{3}$, CGM van Berkel ${ }^{1}$, A J Tipping ${ }^{2}$, HJ Gross ${ }^{3}$,

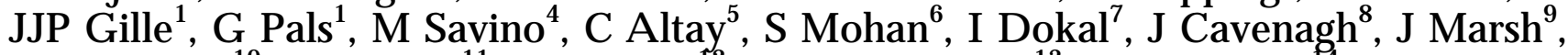 \\ $M$ Van Weel ${ }^{10}$, JJ Ortega ${ }^{11}$, D Schuler ${ }^{12}$, E Samochatova ${ }^{13}$, M K arwacki ${ }^{14}$, \\ A N Bekassy ${ }^{15}, M$ A becasis ${ }^{16}, W$ Ebell ${ }^{17}, M L$ K wee $^{18}, \mathrm{~T}$ de R avel ${ }^{19}, \mathrm{RA}$ G ibson ${ }^{2}$, \\ E Gluckman ${ }^{20},{\mathrm{~F} \mathrm{~A} \text { rwert }^{1}, \mathrm{H} \text { Joenje }}^{1}, \mathrm{~A}$ Savoia $^{4}, \mathrm{H} \mathrm{Hoehn^{3 }}$, JC Pronk ${ }^{1}$ and \\ CG Mathew ${ }^{2}$
}

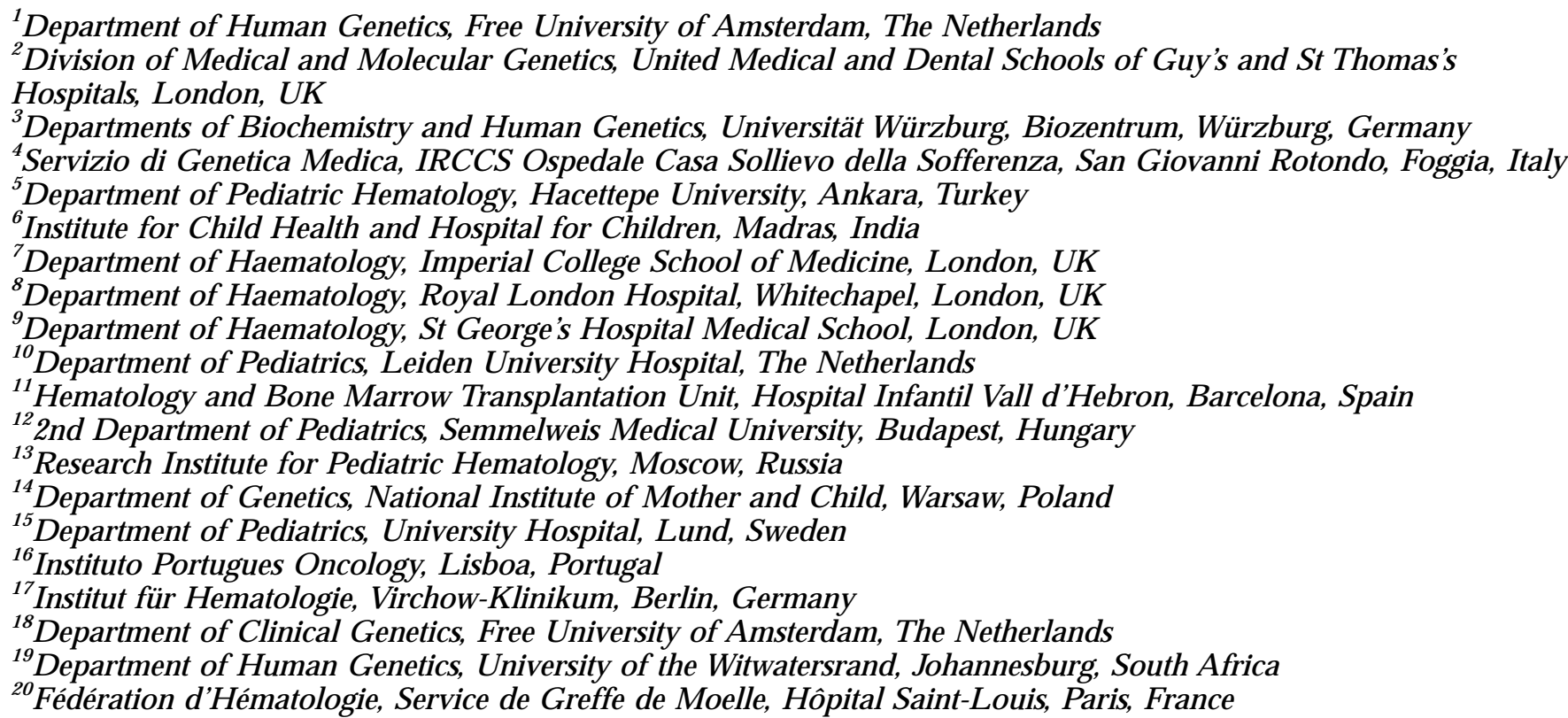

Fanconi anaemia (FA) is a genetically heterogeneous autosomal recessive disorder associated with chromosomal fragility, bone-marrow failure, congenital abnormalities and cancer. The gene for complementation group A (FAA), which accounts for $60-65 \%$ of all cases, has been cloned, and is composed of an open reading frame of $4.3 \mathrm{~kb}$, which is distributed among 43 exons. We have investigated the molecular pathology of FA by screening the FAA gene for mutations in a panel of 90 patients identified by the E uropean FA research group, E U FA R. A highly heterogeneous spectrum of mutations was identified, with $\mathbf{3 1}$ different mutations being detected in 34 patients. The mutations were scattered throughout the gene, and most are likely to result in the absence of the FAA protein. A surprisingly high frequency of intragenic

Correspondence: $\operatorname{Dr} C$ Mathew, Division of Medical and M olecular Genetics UMDS, 8th Floor Guy's Tower, Guy's H ospital, London SE 1 9RT, UK. Tel: + 44(0)171 955 4653; Fax: +44(0)171 955 4644; E-mail: c.mathew@umds.ac.uk

R eceived 23 D ecember 1997; revised 20 M ay 1998; accepted 11 June 1998 


\begin{abstract}
deletions was detected, which removed between 1 and 30 exons from the gene. Most microdeletions and insertions occurred at homopolymeric tracts or direct repeats within the coding sequence. These features have not been observed in the other FA gene which has been cloned to date (FAC) and may be indicative of a higher mutation rate in FAA. This would explain why FA group $A$ is much more common than the other complementation groups. The heterogeneity of the mutation spectrum and the frequency of intragenic deletions present a considerable challenge for the molecular diagnosis of FA . A scan of the entire coding sequence of the FAA gene may be required to detect the causative mutations, and scanning protocols will have to include methods which will detect the deletions in compound heterozygotes.
\end{abstract}

\title{
Keywords: Fanconi anaemia; FAA gene; mutations
}

\section{Introduction}

Fanconi anaemia (FA) is an autosomal recessive inherited disorder which is associated with a variety of congenital anomalies. These include morphometric abnormalities involving mainly the head and face, skeletal malformations particularly of the radial ray, growth retardation, abnormal skin pigmentation, deafness, renal, ocular, genital and cardiac defects. ${ }^{1}$ The cardinal clinical feature, however, is a severe, progressive pancytopaenia, with a mean age of onset of 7-8 years, with death generally occurring within 5 years. The development of acute nonlymphoblastic leukaemia is a common occurrence. The clinical diagnosis is supported by demonstration of hypersensitivity to DNA cross-linking agents ${ }^{2}$ such as diepoxybutane (DEB) and mitomycin C (MMC), or by delayed passage through the $G 2$ phase of the cell cycle. ${ }^{3}$ The increased chromosomal instability in cells from FA patients has led to its classification as a chromosome breakage disorder, but the basis of this presumed failure in DNA repair is not understood (reviewed by Buchwald et $\mathrm{al}^{1}$ and Joenje et al ${ }^{4}$ ). FA is an attractive model for gene therapy, because of the accessibility of the most critically affected tissue (bone marrow), and because proliferating cells which take up a normal copy of the appropriate gene would be expected to have a significant growth advantage over untransfected cells. A functionally active retrovirus vector has been used to transduce CD $34+$ progenitor cells with the FAC gene. $^{5}$

FA is genetically heterogeneous, with eight complementation groups having been described to date. ${ }^{6-8}$ The group $C$ gene was cloned by functional complementation, ${ }^{9}$ and localised to chromosome $9 \mathrm{q} 22.3 .{ }^{6}$ Only 10 mutations have been detected in the FAC gene, ${ }^{9-15}$ including one missense mutation of proven functional significance. ${ }^{16}$ The group $A$ gene (FAA), which accounts for $60-65 \%$ of FA in most popula- tions, ${ }^{17,18}$ was mapped to chromosome $16 q 24.3$ by linkage analysis in FA -A families, ${ }^{19}$ and subsequently identified by both functional complementation ${ }^{20}$ and positional cloning. ${ }^{21}$ The gene has an open reading frame of $4365 \mathrm{bp}$, and encodes a protein with no significant homology to sequences in public databases. The cloning of the major Fanconi anaemia gene has created the opportunity to carry out a detailed investigation of the molecular pathology of the condition. This has been assisted by the characterisation of the genomic structure of the gene, which is composed of 43 exons spread over about $80 \mathrm{~kb}$ of genomic DNA. ${ }^{22}$ Specific issues which can now be investigated include the degree of heterogeneity in the mutational spectrum, the classes of mutation which inactivate the gene, whether specific mutations are associated with a particular geographic or ethnic origin, and whether specific mutations can be correlated with particular clinical phenotypes. Such information will be very useful in the future design of a rational molecular diagnostic strategy for FA and, if genotype/phenotype correlations exist, could influence patient management. The location and nature of the mutations may also shed light on functionally important regions in the gene.

The European Fanconi A naemia Research Group (EUFAR) is undertaking a major survey of mutations in the FAA gene in an extensive panel of FA patients from $E$ urope, $A$ sia and the $M$ iddle $E$ ast. We now report the existence of a very heterogeneous mutational spectrum in FAA, and the identification of 29 novel mutations.

\section{Methods}

Patients and Samples

The clinical diagnosis of FA was based on typical findings including a progressive pancytopaenia and characteristic congenital abnormalities such as radial defects. ${ }^{1,4}$ The diagnosis was confirmed in all cases by the demonstration of 
either hypersensitivity to M M C or DE B, or by observation of a delayed $\mathrm{G} 2$ phase in the cell cycle, as previously described. ${ }^{3}$ Patients were recruited to the study via the framework of the E uropean Concerted A ction on FA R esearch (EUFA R), or referred by haematology departments in the constituent countries. Lymphoblastoid cell lines ( $L C L s)$ were prepared from peripheral blood cells, subjected to cell fusion with the prototype FA -A cell line HSC 720T, ${ }^{23}$ and tested for complementation. ${ }^{6,7}$ A bout $25 \%$ of LCL s could not be classified, because they were resistant to $\mathrm{M} \mathrm{MC} .{ }^{24}$ In some cases, samples were only available as fibroblast cell lines of unknown complementation group, or as DNA extracted from peripheral blood lymphocytes. In cases of unknown complementation group in which samples from other affected and/or unaffected family members were available, D NA s were typed with microsatellite markers closely linked to the FAA gene, ${ }^{21}$ to select cases most likely to be from group A. DNA and R NA were extracted from cell lines as described. ${ }^{10} \mathrm{G}$ enomic DNA was extracted from peripheral blood samples of FA patients with no cell lines, but cell counts were generally too low to obtain usable yields of R NA.

\section{Complementation Analysis}

Cell fusions to genetically marked reference cell lines from known FA complementation groups was carried out, as previously described. ${ }^{8}$

\section{Mutation Screening}

The methods used by the three laboratories to scan the FAA coding sequence for mutations were as follows:

1) In A msterdam, screening was carried out on cell lines from 36 FA patients classified as FA-A by complementation analysis. Total RNA was extracted and the FAA mRNA reverse-transcribed and amplified by $P C R$ (RT-PCR) in nine overlapping fragments using specific primers with T 7 and SP 6 extensions, sized by gel electrophoresis, and purified with Q iagen kits. PCR products were then digested with restriction enzymes to generate two fragments of about $300 \mathrm{bp}$, suitable for single-stranded conformational polymorphism (SSCP) and heteroduplex (HD) analysis. PCR primer and restriction enzyme combinations were (primers written in $5^{\prime}-3^{\prime}$ orientation):

1) AATTGTCTCTCAGCAAAGTGAT and CGTGAAGATGCCACAA/Bglll;

2) TGTTCTCCCGTCTTTCCTTC and GTGAGCA GAGGGTGTGTC/Bgl I;

3) GTTCGGAGTGTTCAGTGGAC and GGGTGGGTGGAGAATGTG/Taql;

4) GCCCTGGTCTTCCTGTTTA and CCTCAGCA GAGTTGGGTTCT/Pvull;

5) GACTCCCGTGTGGCGTTTAT and CAGCA CATGTGGGGCACTCA/E coRI;

6) CTGCCAGCTGCTCCGTCACC and GTGGAAGTCCTGCCGTTCAG/Pvull;

7) TCAGATACTGAACGGCAGGACT and CTCA GAGTTGACCA A GTGGAAG/BamHI;
8) GCAGCAGCTTCCAGGCAGAACA and CTGTGGTGCTATTTGAGGTCA G/Pstl;

9) GATGGGCCTGCTGTCGTCACAT and CAGGTCCCGTCA AAGAGATGA/Pvull;

Restriction fragments were then mixed with the same products generated from the wild type CDNA, heated for 2 min in a boiling waterbath, cooled on ice, and analysed on a $20 \%$ acrylamide gel with silver staining to visualise the bands (Pharmacia Phast system). Fragments showing aberrant SSCP or heteroduplex patterns were sequenced. A Iternatively the 43 exons of FAA were amplified from genomic DNA with primers located 40-60 bp from exon boundaries. ${ }^{25,26}$ Fragments were analysed on the Pharmacia Phast system. The effect of mutations predicted to cause premature termination of translation were confirmed by an in vitro transcription/ translation protein truncation assay of CDNA as described. ${ }^{20}$

2) In L ondon, screening of the FAA coding sequence was initiated in five patients classified as group $A$ by complementation analysis. The coding sequence was amplified in seven overlapping fragments by RT-PCR and automated sequencing performed on a PerkinElmer/A pplied Biosystems 377 DNA sequencer with fluorecent dye-terminator sequencing kits, as recommended by the suppliers. Intragenic deletions detected in the CDNA were confirmed in homozygotes by exon amplification from genomic DNA, and in compound heterozygotes by a quantitative fluorescent gene dosage assay which measures the relative intensity of FA A gene fragments compared to an FAC gene control ${ }^{27}$ (and M organ N V et al, in preparation). A further $27 \mathrm{FA}$ patients from whom no cell lines were available, and who were therefore unclassified with respect to complementation group, were screened by amplification of the individual exons and SSCP/HD analysis of ${ }^{32} \mathrm{P}$-labelled PCR products as previously described, ${ }^{10}$ using published primers. ${ }^{25,26}$ Fragments with band shifts were characterised by sequencing independent PCR products on both strands and mutations confirmed by restriction site analysis.

3) In Wurzburg, the FAA coding sequence was screened in 22 FA cell lines of unknown complementation group. The exons were amplified, screened for mutations by SSCP analysis on the Pharmacia Phast system, and band shifts characterised by direct sequencing. The effect of the mutations detected was analysed by RT-PCR and sequencing. Deletions of genomic DNA were confirmed by the detection of aberrant bands on Southern blots using the FAA CDNA as a probe.

The total number of patients screened was 90 , of whom 41 were FA -A by complementation analysis. Since about $60 \%$ of all FA patients are from group $A,{ }^{17,18}$ there are approximately $41+(49) \times 0.6=70 \mathrm{FA}-\mathrm{A}$ patients in the total screening panel.

In order to distinguish rare polymorphic variants from pathogenic mutations, control chromosomes were screened for the missense mutations found in FA patients, and the segregation of all mutations was analysed in FA families from whom other family members were available. 


\section{Results}

A total of 31 different mutations which are likely to be pathogenic were detected in this study (see Figure 1 and Table 1), 29 of which are novel mutations. M ost classes of mutation were detected, including missense mutations, stop codons, microdeletions or insertions which generally caused frameshifts, splice site mutations and large intragenic deletions. M ost of the large deletions were detected by consistent lack of amplification of the relevant exons in patients who were homozygous for the deletion; the exons immediately proximal and distal to the deletion amplified successfully. In compound heterozygotes the endpoints were fully or partially defined by quantitative fluorescent PCR. ${ }^{27}$ In seven of the nine microdeletions or insertions, the mutation occurred either at homopolymeric tracts or by removal of one or two di- or tri-nucleotide direct repeats. The four putative missense mutations, D598N, S858R, R 1055W and S1088F, are non-conservative substitutions which were not seen in 100 control chromosomes. The most common mutation was 1263delF, which was present in five apparently unrelated patients from five European countries; 40linsC has also been described by Levran et al. ${ }^{25}$ The mutations were scattered throughout the coding sequence of the FAA gene (Figure 1). M utations were detected in 34 patients from the screening panel, which contained approximately 70 patients from FA -A (see M ethods). This indicates an overall detection rate of $49 \%$, which was very similar in all three participating laboratories. The heterogeneity of the mutational spectrum is evident from the fact that 19 of the 25 patients from non-consanguineous matings were compound heterozygotes for two different mutant alleles. The total number of independent mutant alleles in the 34 mutation-positive patients is $59(25 \times 2+9)$. We have now detected $47(79.7 \%)$ of these alleles, (Table 1 and Lo Ten Foe Jr et al, ${ }^{20}$ Fanconi A naemia/
B reast Cancer Consortium. ${ }^{21}$ ) which comprise 31 different mutations.

The geographic and ethnic spectrum of FAA mutations is shown in Table 2. These data are a collation of the mutation data from the present study, and three other studies from the EUFAR group, ${ }^{20,21,26}$ and comprise a total of 43 different mutations. The largest numbers of patients screened from single population groups have been from Italy and Germany, and these data reinforce the picture of extensive genetic heterogeneity even within a single country.

In addition to the pathogenic mutations, 13 sequence changes which give rise to amino acid substitutions were detected which are either common polymorphisms or rare variants (Table 3 ). Five of these are clearly polymorphisms, since they were present in 9-50\% of the control chromosomes. M 717 is present in the FAA CDNA which was cloned by functional complementation, ${ }^{20}$ and is therefore unlikely to affect the function of the protein. E $878 \mathrm{Q}$ does not segregate in the single consanguineous family in which it was detected, since it was present in the heterozygous state in two of three affected siblings, and absent in the third. $V 6 D$ is one of three mutations in a multiplex family in which the other two mutations would produce a truncated protein product. V 295L, R 296K and S303T were all detected in the same Black South A frican FA patient, who has subsequently been shown to be non- $A$ by complementation analysis. R $245 \mathrm{~K}$ was also detected in a non-A patient from this population. The complementation group of the patient with the S309N mutation cannot be resolved as the cell-line is resistant to MMC. A large number of other polymorphisms which do not alter the coding sequence or which occur in non-coding regions not involved in mRNA splicing were detected. These have been submitted to the Fanconi A naemia Mutation Database (http:/ /www.rockefeller.edu/fanconi/mutate).

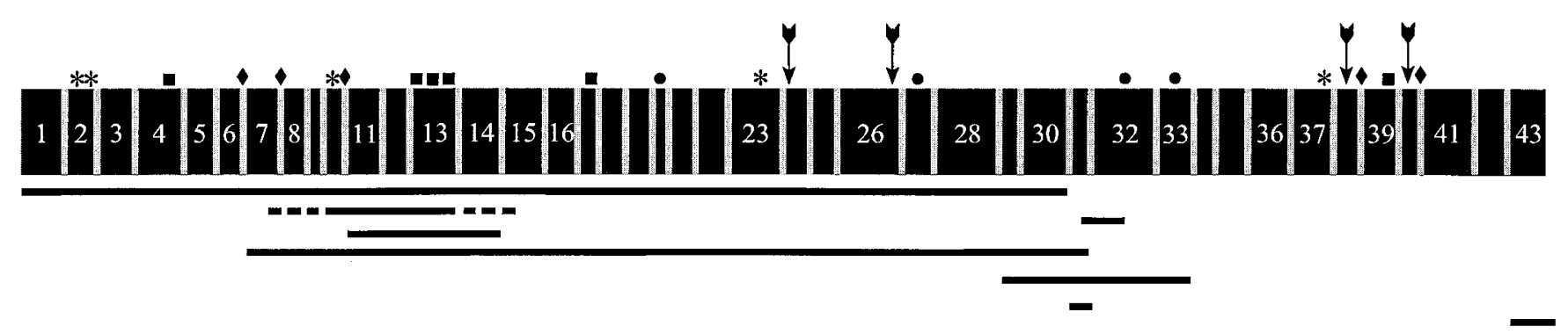

Figure 1 M utations detected in the FA A gene in Fanconi anaemia patients. The figure is a schematic representation of the 43 exons of the FAA gene: $*=$ nonsense mutation; $\mathbf{\square}=$ frameshift; $\bullet=$ splice site; $\bullet=$ missense; $\downarrow=$ microdeletion; $-=$ large deletion. 
Table 1 M utations detected in the FAA gene of Fanconi anaemia patients

\begin{tabular}{|c|c|c|c|c|c|c|}
\hline Patient code & Mutation & E ffect & Exon & State & $\mathrm{N}$ & O ther mutation \\
\hline$\overline{7 P I R}$ & 1-2981del & deletion & $1-30$ & HOM & 2 & - \\
\hline E U FA 353 & $154 \mathrm{C} \rightarrow \mathrm{T}$ & R 52X & 2 & HET & 1 & N ot detected \\
\hline E U FA 127 & $163 \mathrm{C} \rightarrow \mathrm{T}$ & Q 55X & 2 & HET & 1 & 1263delF \\
\hline E U FA 426 & 401 ins $\mathrm{Ca}^{\mathrm{a}}$ & frameshift & 4 & HET & 1 & Not detected \\
\hline E U FA 123 & IV S6- $2 A \rightarrow G$ & del13A A & i6 & HET & 1 & N ot detected \\
\hline PRU 80665 & 597-3066del & deletion & $7-31$ & $\mathrm{HOM}$ & 2 & - \\
\hline E U FA 444 & $827-1225 d$ elb & deletion & $10-13^{b}$ & HET & 1 & 1115-1118deld \\
\hline $12 C W L$ & $856 \mathrm{C} \rightarrow \mathrm{T}$ & Q 286X & 10 & HET & 1 & Not detected \\
\hline PRU 78236 & IV S10-1G $\rightarrow A$ & exon 10 skip & i10 & $\mathrm{HOMC}$ & 1 & - \\
\hline E U FA 586 & 894-1359del & deletion & $11-14$ & $\mathrm{HOMC}$ & 1 & - \\
\hline E U FA 418 & 1115-1118del & frameshift & 13 & HET & 2 & Not detected \\
\hline 16V R O & 1164-1165del & frameshift & 13 & HET & 1 & 4010delG +18 \\
\hline E U FA 763 & 1191-1194del & frameshift & 13 & HET & 1 & N ot detected \\
\hline E U FA 704 & 1615delG & frameshift & 17 & $\mathrm{HOM}$ & 2 & - \\
\hline E U FA 134 & $1792 \mathrm{G} \rightarrow \mathrm{A}$ & D 598N & 20 & HET & 2 & Not detected \\
\hline E U FA 245 & $1792 \mathrm{G} \rightarrow \mathrm{A}$ & D 598N & 20 & HET & 2 & Not detected \\
\hline PRU 65248 & $2107 \mathrm{C} \rightarrow \mathrm{T}$ & Q 703X & 23 & $\mathrm{HOMC}$ & 1 & - \\
\hline PR U 91730 & 2167-2169del & 723delL & 24 & HET & 1 & IV S38-1G $\rightarrow$ C \\
\hline PRU 79892 & 2495-2497del & 832delF & 26 & $\mathrm{HOMC}$ & 1 & - \\
\hline E U FA 186 & $2574 C \rightarrow G$ & S828R & 27 & HET & 1 & N ot detected \\
\hline 3VHE & 2779-3348del & deletion & $29-33$ & $\mathrm{HOM}$ & 2 & - \\
\hline B D 11 & 2982-3066del & deletion & 31 & $\mathrm{HOMC}$ & 1 & - \\
\hline E U FA 043 & 3061-3154del & frameshift & $31-32$ & $\mathrm{HOM}$ & 1 & - \\
\hline PRU 77959 & $3163 \mathrm{C} \rightarrow \mathrm{T}$ & R 1055W & 32 & $\mathrm{HOMC}$ & 1 & - \\
\hline PRU 66279 & $3263 \mathrm{C} \rightarrow \mathrm{T}$ & S1088F & 33 & $\mathrm{HOMC}$ & 1 & - \\
\hline E U FA 275 & $3760 \mathrm{G} \rightarrow \mathrm{T}$ & E 1254X & 37 & HET & 1 & IVS7+5G $\rightarrow A^{e}$ \\
\hline E U FA 006 & 3788-3790del & 1263delF & 38 & HET & 1 & 1360-1826dele \\
\hline E U FA 483 & 3788-3790del & 1263delF & 38 & HET & 5 & Not detected \\
\hline E U FA 507 & 3788-3790del & 1263delF & 38 & HET & 5 & N ot detected \\
\hline E U FA 689 & 3788-3790del & 1263delF & 38 & $\mathrm{HOMC}$ & 5 & - \\
\hline PRU 91730 & IV S38-1G $\rightarrow$ C & exon 38 skip & i38 & HET & 1 & 2167-2169del \\
\hline E U FA 255 & 3920delA & frameshift & 39 & HET & 1 & Not detected \\
\hline 16V R O & 4010delG +18f & exon 40 skip & 40/i40 & HET & 1 & 1164-1165del \\
\hline E U FA 139 & IV S40+1-18del & exon 40 skip & i40 & $\mathrm{HOMC}$ & 1 & - \\
\hline A 528 & 4267-4404del & deletion & 43 & HET & 3 & 1263delF \\
\hline A 598 & 4267-4404del & deletion & 43 & $\mathrm{HOM}$ & 3 & - \\
\hline
\end{tabular}

a25; bD eletion endpoints not defined; 'CConsanguineous; d21; e20; numbering of cD NA from initiation codon; f18bp of IV S40; N =N o. of FAA alleles containing the mutation (consanguineous alleles are counted as 1); HO M =homozygous; HET =heterozygous.

\section{Discussion}

The most striking feature of the mutation screening data reported here is the extensive heterogeneity of the mutational spectrum of the FAA gene. M utations were detected in 34 patients, and 47 of the predicted 59 mutant alleles were identified in this group (Table 1 ). These 59 alleles were comprised of no fewer than 31 different mutations, which indicates that the majority of FA-A patients who are not the offspring of related parents will be compound heterozygotes for two different mutant alleles. This heterogeneity was not only a result of the variety of the geographic and ethnic origins of the patients screened, since it was also found within populations of a particular country, with 12 different mutations already defined in the Italian population, ${ }^{21,26}$ and eight mutations in the German patients (Table 2). There was no evidence for common mutations in any particular population, although some mutations such as 1263delF and 1115-1118del were found in multiple unrelated patients from different populations.

The heterogeneity also extended to the class and location within the gene of the mutations detected. A Imost all classes of mutations were observed, including a surprisingly high number of large intragenic deletions which removed one or more exons; these accounted for eight of the 31 mutations (26\%) in this study (Table 1). No deletions of this sort have yet been observed in the FAC gene, ${ }^{13,14}$ which suggests that there 
Table 2 Countries of origin of Fanconi anaemia patients with FAA gene mutations

\begin{tabular}{|c|c|}
\hline Country & M utations detected \\
\hline B ritain & $\begin{array}{l}\text { 401insC, 1115-1118del, D 598N, 723delL } \\
\text { IV S38-1G } \rightarrow \text { C }\end{array}$ \\
\hline Czech R epublic & 1164-1165del, 1263delF, 4010delG +18 \\
\hline E gypt & IV S7+5G $\rightarrow$ T, 3061-3154del \\
\hline France & 1115-1118del, 1191-1194del, 1263delF \\
\hline G ermany & $\begin{array}{l}\text { Q } 55 X, \text { IV S6-2A } \rightarrow \text { G, Q 286X, D 598N, } \\
\text { S858R, ex29-33del, 1263delF, } \\
\text { IV S40+1-18del }\end{array}$ \\
\hline H ungary & 1263delF \\
\hline India & $\begin{array}{l}\text { ex7-31del, IV S10-1G } \rightarrow \text { A , 823delF, } \\
\text { R 1055W }\end{array}$ \\
\hline Iran & ex1-30del, S1088F, ex43del \\
\hline Ireland & ex11-14del \\
\hline Italy & $\begin{array}{l}\text { Q 264X, IV S9+3delA, IV S10+1G } \rightarrow \text { T, } \\
\text { IV S14+1G } \rightarrow \text { C, ex18-21del, Q 669X, } \\
\text { Q 772X, IV S28+83C } \rightarrow \text { G, } \\
\text { 2831dup2812-2830, 3559insG, 3638-3639del, } \\
\text { D 1359Y }\end{array}$ \\
\hline Lebanon & Q 703X \\
\hline $\mathrm{N}$ etherlands & 3920delA \\
\hline Pakistan & ex31del \\
\hline Poland & R 52X, 1615delG \\
\hline Spain & $\begin{array}{l}\text { IV S7+5G } \rightarrow \text { A, ex10-13del*, 1115-1118del, } \\
\text { E } 1254 X, 1263 \text { delF }\end{array}$ \\
\hline Turkey & ex43del \\
\hline
\end{tabular}

*D eletion endpoints not defined.

Table 3 Polymorphisms and variants in the coding sequence of the Fanconi anaemia FAA gene

\begin{tabular}{lcll}
\hline M utation & Exon & E ffect & Frequency $^{1}$ \\
\hline $17 T \rightarrow A$ & 1 & V 6D & 0.01 \\
$734 \mathrm{G} \rightarrow \mathrm{A}$ & 8 & $\mathrm{R} 245 \mathrm{~K}$ & $0.00^{2}$ \\
$795 \mathrm{G} \rightarrow \mathrm{A}$ & 9 & $\mathrm{~A} 266 \mathrm{~T}$ & 0.50 \\
$883 \mathrm{G} \rightarrow \mathrm{C}$ & 10 & $\mathrm{~V} 295 \mathrm{~L}$ & $0.00^{2}$ \\
$887 \mathrm{G} \rightarrow \mathrm{A}$ & 10 & $\mathrm{R} 296 \mathrm{~K}$ & $0.00^{2}$ \\
$908 \mathrm{G} \rightarrow \mathrm{C}$ & 11 & $\mathrm{~S} 303 \mathrm{~T}$ & $0.00^{2}$ \\
$926 \mathrm{G} \rightarrow \mathrm{A}$ & 11 & $\mathrm{~S} 309 \mathrm{~N}$ & $0.00^{2}$ \\
$1235 \mathrm{C} \rightarrow \mathrm{T}$ & 14 & $\mathrm{~A} 412 \mathrm{~V}$ & 0.09 \\
$1501 \mathrm{~A} \rightarrow \mathrm{G}$ & 16 & $\mathrm{~S} 501 \mathrm{G}$ & 0.34 \\
$2151 \mathrm{G} \rightarrow \mathrm{T}$ & 23 & $\mathrm{M} 717 \mathrm{I}$ & 0.01 \\
$2426 \mathrm{G} \rightarrow \mathrm{A}$ & 26 & $\mathrm{G} 809 \mathrm{D}$ & 0.45 \\
$2632 \mathrm{G} \rightarrow \mathrm{C}$ & 28 & $\mathrm{E} \mathrm{878Q}$ & $0.00^{3}$ \\
$3982 \mathrm{~A} \rightarrow \mathrm{G}$ & 40 & $\mathrm{~T} 1328 \mathrm{~A}$ & 0.09
\end{tabular}

${ }^{1}$ Frequency of rare allele in 100 European control chromosomes.

${ }^{2}$ Conservative substitution in B lack South A frican patients.

3 Variant does not segregate with FA phenotype. may be structural features of the FAA gene, such as repetitive sequence elements, which promote unequal recombination and the generation of deletions. This apparent genetic instability of the FAA gene suggests that it may have a higher mutation rate than the genes for the other FA complementation groups, which would explain why FA -A accounts for about two-thirds of all FA patients. Since most of the mutations are deletions, frameshifts or stop codons, they would be predicted to generate null alleles, although residual function for part of the protein cannot be excluded. This would be interesting to analyse, particularly for mutations such as 4267-4404del, which removes only the final exon of the FAA gene. The status of the missense mutations can be resolved by site-directed mutagenesis and analysis by functional complementation, as was done for several mutations in the FAC gene. ${ }^{15,28}$ The mutations are scattered throughout the coding sequence (Figure 1 ), with no compelling evidence of mutation 'hotspots' at present.

In this study, mutations were detected in 34 patients, which is $49 \%$ of the predicted number of FA -A cases which were screened. A Iso, 47 of 59 mutant alleles were identified in these 34 patients. In the other two published studies, Savino et al ${ }^{26}$ detected mutations in $29 \%$ of probable FA -A patients, and Levran et $\mathrm{al}^{25}$ in $69 \%$ of patients. H owever, 14 of 40 mutations in the latter study were amino acid substitutions, and their effect on the function of the FAA protein is not yet known. These data indicate that a substantial proportion of mutations were not detected by current scanning protocols. This may be partly explained by the limited sensitivity of the SSCP technique, which detects $70-90 \%$ of mutations, depending on the size of fragment being screened and the gel conditions used. ${ }^{29}$ H owever, an important additional factor in the context of the FAA gene is the relatively large number of intragenic deletions superimposed upon high mutational heterogeneity. Thus, if compound heterozygotes for a 'micro' mutation and an intragenic deletion are screened only by SSCP of exons, the deletion would not be detected since all exons would be amplified from the intact allele. This would also apply if two nonoverlapping deletions were present. A rational screening strategy must therefore be devised which screens for 'micro' mutations by methods such as SSCP, and for deletions of entire exons by, for example, Southern blot analysis. The latter will be facilitated by the availability of a detailed restriction map of the entire $80 \mathrm{~kb}$ of genomic sequence of the FAA gene. ${ }^{22}$ This will be of 
considerable diagnostic importance, since knowledge of the causative mutation will permit rapid prenatal diagnosis on the basis of a molecular test. It will also allow rapid classification of patients as FA -A or non-A in cases where an MMC-sensitive cell line is not available.

In addition to the heterogeneous spectrum of pathogenic mutations, there is also an extensive degree of polymorphism in the FAA gene. The pathogenic status of an additional 13 missense mutations (see Table 3) was assessed by

(1) scanning the entire coding sequence for other mutations,

(2) screening a panel of control chromosomes,

(3) checking for co-segregation with the clinical phenotype, and

(4) complementation analysis.

This combination of approaches indicated that most of these mutations are unlikely to affect the function of the FAA protein, and emphasises the need for thorough evaluation of the significance of individual missense mutations.

This study and two other very recent publications ${ }^{25,26}$ represent the start of a concerted effort to describe the molecular pathology of the major Fanconi anaemia gene. The current data indicate that a great deal more work needs to be done to define the mutation spectrum of the FAA gene in the major populations. The great heterogeneity of mutations will not facilitate correlation of clinical phenotype with specific mutations, since these will be rare, and will generally be found in compound heterozygotes. H owever, future work will be directed towards an analysis of the position of mutations within the gene in relation to phenotype, since this approach has yielded functional insights for genes such as BRCA $1 .{ }^{30}$

\section{Acknowledgements}

We thank the families with Fanconi anaemia for their cooperation in providing blood samples, Dr D Schindler for cell lines, and Drs S Ball, J Evans, E Gordon-Smith, F B reatnach, A N ewland, S R assam, I R oberts, S Temtamy, W Friedrich, B Gautier, and many other physicians of the EUFAR collaboration for referring patients. This study was supported by EUFAR, the Fanconi A naemia R esearch Fund Inc. (U SA ), Fanconi A naemia B reakthrough (U K), D eutsche Fanconi A naemia Hilfe e.V., the Italian A ssociation for Fanconi A naemia R esearch, A ssociation Française de $\mathrm{M}$ al- adie de Fanconi, Nederlands Stichting Fanconi A nemie, the I talian M inistry of $\mathrm{H}$ ealth and Telethon (E.364).

\section{References}

1 Buchwald $M$, J oenje $H$, A uerbach A D : Fanconi anaemia. In: Scriver CR, B eaudet A L, Sly WS, Valle D (eds). The $M$ etabolic and M olecular B asis of I nherited D isease 7th ed. M cG raw-H ill: N ew York, 1997.

2 Schroeder TM, A nschütz F, K nopp A : Spontane Chromosomenaberrationen bei familiärer Panmyelopathie. H umangenetik 1964; 1: 194-196.

3 Seyschab H, Friedl R, Sun Y et al: Comparative evaluation of diepoxybutane sensitivity and cell cycle blockage in the diagnosis of Fanconi anaemia. Blood 1995; 85: 2233-2237.

4 Joenje H, Mathew C, Gluckman E: Fanconi anemia research: current status and prospects. E ur J C ancer 1995; 31A , 268-272.

5 Liu JM, Buchwald M, Walsh CE, Young NS: Fanconi anemia and novel strategies for therapy. Blood 1994; 84: 3995-4007.

6 Strathdee CA, D uncan A M V, Buchwald M : E vidence for at least four Fanconi anaemia genes including FA CC on chromosome 9. Nat G enet 1992; 1: 196-198.

7 Joenje H, L o Ten Foe J R, O ostra A B et al: Classification of Fanconi anaemia patients by complementation analysis: evidence for a fifth genetic subtype. Blood 1995; 86: 2156-2160.

8 Joenje $\mathrm{H}, \mathrm{O}$ ostra A B, Wijker $\mathrm{M}$ et al: Evidence for at least eight Fanconi A nemia genes. A m J H um G enet 1997; 61: 940-944.

9 Strathdee CA, Gavish H, Shannon WR, Buchwald M: Cloning of CDNA S for Fanconi's A naemia by functional complementation. N ature 1992; 356: 763-767.

$10 \mathrm{G}$ ibson R A, H ajianpour A, M urer-O rlando $M$, B uchwald $M, M$ athew $C G$ : A nonsense mutation and exon skipping in the Fanconi A naemia group $\mathrm{C}$ gene. $\mathrm{H}$ um $\mathrm{M}$ ol $\mathrm{G}$ enet 1993; 2: 797-799.

11 Whitney MA, Saito $H$, Jakobs PM, Gibson RA, Moses $\mathrm{RE}, \mathrm{Grompe} \mathrm{M}$ : A common mutation in the FA CC gene causes Fanconi anaemia in A shkenazi Jews. $\mathrm{N}$ at $\mathrm{G}$ enet 1993; 4: 202-205.

12 M urer-O rlando $M$, L lerena J C J r, Birjandi F, Gibson R A, $M$ athew CG: FACC gene mutations and early prenatal diagnosis of Fanconi's anaemia. $L$ ancet 1993; 342: 686.

13 Verlander $\mathrm{PC}, \mathrm{L}$ in J D, U dono MU et al: Mutation analysis of the Fanconi anemia gene FA CC. A m J H um G enet 1994; 54: 595-601.

14 Gibson RA, Morgan NV, Goldstein LH et al: Novel mutations and polymorphisms in the Fanconi anaemia group C gene. H um M utat 1996; 8:140-148.

15 Lo Ten Foe J R, R ooimans M A, J oenje H, A rwert F : N ovel frameshift mutation (1806insA) in exon 14 of the Fanconi anemia C gene, FAC. H um M utat 1996; 7: 264-265.

16 G avish H, dos Santos CC, B uchwald M: A L eu ${ }_{554}$-to-Pro substitution completely abolishes the functional complementing activity of the Fanconi anemia (FACC) protein. H um M ol G enet 1993; 2: 123-126.

17 Buchwald $M$ : Complementation groups: one or more per gene? Nat G enet 1995 11: 228-230. 
18 Joenje $\mathrm{H}$, for the European Fanconi A nemia Research Group: Fanconi anaemia complementation groups in Germany and the Netherlands. Hum G enet 1996; 97: 280-282.

19 Pronk J C, Gibson R A, Savoia A et al: Localisation of the Fanconi anaemia complementation group $A$ gene to chromosome 16q24.3. Nat G enet 1995; 11: 338-340.

20 Lo Ten Foe J R, R ooimans M A, B osnovan-Collins L et al: Expression cloning of a CDNA for the major Fanconi anaemia gene, FA A. Nat Genet 1996; 14: 320-323.

21 The Fanconi A naemia/B reast Cancer Consortium:* Positional cloning of the Fanconi A naemia $G$ roup $A$ G ene. Nat G enet 1996; 14: 324-328.

*Group 1: S A postolou, SA Whitmore, J Crawford, G Lennon, GR Sutherland, DF Callen (these first two authors contributed equally); Group 2: L Ianzano, M Savino, M D'A polito, A Notarangelo, E M eneo, M R Piemontese, L Zelante, A Savoia; Group 3: RA Gibson, A J Tipping, NV Morgan, S H assock, S Jansen, TJ de $R$ avel, $C$ van Berkel, J Pronk, DF E aston, CG M athew; Group 4: $O$ Levran, PC Verlander, SD Batish, T E rlich, A D A uerbach; Group 5: A -M Cleton-Jansen, EW M oerland, CJ Cornelisse; Group 6: NA Doggett, LL Deaven, RK Moyzis

22 Ianzano $L$, d'A polito $M$, Centra $M$ et al: The genomic organization of the Fanconi anaemia group A (FA A) gene. G enomics 1997; 41: 309-314.
23 D uckworth-R ysiecki G, Cornish K, Clarke CA, B uchwald $\mathrm{M}$ : Identification of two complementation groups in Fanconi anemia. Somat Cell M ol G enet 1985; 11: 35-41.

24 Lo Ten Foe JR, K wee M L, R ooimans MA et al: Somatic mosaicism in Fanconi anaemia: molecular basis and clinical significance. E ur J H um G enet 1997; 5: 137-148.

25 L evran $\mathrm{O}$, E rlich T, M agdalena $\mathrm{N}$ et al: Sequence variation in the Fanconi anemia gene FA A. P roc N atl A cad Sci USA 1997; 94: 13051-13056.

26 Savino $M$, Ianzano L, Strippoli $P$ et al: Mutations of the Fanconi anemia group A (FAA) gene in I talian patients. A m J H um G enet 1997; 61: 1246-1253.

$27 \mathrm{Yau}$ SC, Bobrow M, Mathew CG, A bbs S: A ccurate diagnosis of carriers of deletions and duplications in Duchenne/B ecker M uscular Dystrophy by fluorescent dosage analysis. J $M$ ed $G$ enet 1996; 33: 550-558.

28 Lo Ten Foe J R, B arel MT, Tuss PO, Digweed M, A rwert F Joenje $H$ : Sequence variations in the Fanconi anaemia $C$ gene, FAC: pathogenicity of 1806insA and R $548 \mathrm{X}$ and recognition of D $195 \mathrm{~V}$ as a polymorphic variant. Hum G enet 1996; 98: 522-523.

$29 \mathrm{G}$ rompe $\mathrm{M}$ : The rapid detection of unknown mutations in nucleic acids. Nat Genet 1994; 5: 111-117.

30 Gayther SA, Warren W, Mazoyer S et al: Germline mutations of the BRCA 1 gene in breast and ovarian cancer families provide evidence for a genotype-phenotype correlation. N at G enet 1995; 11: 428-433. 